\title{
Gender, the state and the audit profession: evidence from Spain (1942-88)
}

\author{
Nieves Carrera, Isabel Gutiérrez and Salvador Carmona \\ Universidad Carlos III, Getafe, Spain
}

\begin{abstract}
Extant knowledge on gender and auditing overwhelmingly relies on evidence gathered from a limited group of Anglo-Saxon countries. It is widely admitted, however, that gender issues are affected by the institutional contexts of the investigation. The AngloSaxon settings, we contend, embrace a number of idiosyncratic, institutional characteristics that advise caution in the generalizability of results. Our study addresses the role of gender in Spanish audit practice during the period 1942 to 1988. The environment of the Spanish audit profession witnessed the peaceful transition from a dictatorship to a full-fledged democracy as well as the emergence of a free market economy from a system characterized by stiff economic autarchy and an overriding intervention of the state in the economy. We found that the dominant role of the state in Spanish society affected the structure of the audit profession and made impossible the emergence of an autonomous project. In particular, our findings reveal that the audit profession did not have an independent strategy about the role of women at work, but mimicked the attitudes deployed by the state during our observation period.
\end{abstract}

\section{INTRODUCTION}

The practice of accounting has come to be perceived in many different ways (Hopwood, 1987: 65). The accounting research agenda has considerably benefited from investigations of new perceptions of accounting, as exemplified by gender studies. Since the publication in 1987 of a seminal, special issue of Accounting, Organizations and Society on gender and accounting, much valuable knowledge has been gleaned about the discursive nature of gender notions. Such investigations have addressed the role of gender in areas ranging from accounting research (Oakes and Hammond, 1995) through accounting education (Tyson, 1988) to the practice of accountancy (Tinker and Neimark, 1987; Lehman, 1992). As far as the latter area is concerned, studies on gender have identified a number of social factors that restrict the access and promotion of women into the profession (e.g., Kirkham and Loft, 1993; Anderson et al., 1994). 
A distinctive characteristic of the overall literature on gender is its focus on 'First World' countries (e.g., Crompton and Sanderson, 1990: 184). In the particular case of research on gender and accountancy, investigations follow a much narrower pattern than that shown by the overall gender literature and overwhelmingly concentrate on a limited number of Anglo-Saxon settings (e.g., North America and the United Kingdom; see García Benau and Humphrey, 1992; Bougen and Vázquez, 1997), and that context bias also applies to studies examining the role of minorities in the profession (e.g., Hammond, 1997a; Mynatt et al., 1997). Although the Anglo-Saxon context indeed constitutes a relevant setting, it also embraces a number of idiosyncratic, institutional elements. In England and Wales, for example, the profession enjoys a tradition of high social status, high salaries and considerable self-regulative capabilities. Caution, thus, must be advised in generalizing conclusions beyond such contexts.

In other equally relevant settings, the wider contexts of the profession are characterized by political and economic regimes which are significantly different from the liberal democracies and free market economies that identify many Anglo-Saxon countries (e.g., military dictatorships, overriding intervention of the state in the economy; see Jarausch, 1990; Torstendahl and Burrage, 1990). Such diverse contexts, we argue, make relevant the investigation of aspects such as the profession-state relations to developing a more comprehensive understanding of professionalization endeavours (Chua and Poullaos, 1993, 1998). By studying the role of gender in institutional contexts different from those exemplified by the extensively studied Anglo-Saxon ones, further insights may be gained about the role of gender in the development of the audit profession.

Our investigation is supported by evidence gathered from the Spanish auditing context during the period from 1942 to 1988 . This observation period starts with the inception of the oldest Spanish professional association of auditors which is still in operation (Instituto de Censores Jurados de Cuentas, ICJCE), and ends with the enactment of the Spanish audit law (SAL). The SAL implemented the provisions of the European Union's Eighth Directive (EUED) into Spanish law and constituted the earliest legislation in the country's history that comprehensively focused on the audit profession. It is, therefore, widely regarded as an attempt to transform the conduct of auditing in Spain (Bougen, 1997: 757). In particular, the SAL did not only attempt to conform to the EUED but, more importantly, intended to enact 'a framework of guarantees for all those interested in the truthfulness of audited financial statements' (ibid.: 766). To attain that goal, the SAL created a governmental body, the Instituto de Contabilidad y Auditor $\tilde{\boldsymbol{a}}$ de Cuentas (Institute of Accounting and Auditing, ICAC), 'to embrace the entire auditing activity' (Bougen and Vázquez, 1997: 14).

As noted below, the Spanish setting witnessed the peaceful replacement of a far right-wing military dictatorship by a full-fledged, Western democracy, as well as the substitution of a system of economic autarchy and considerable intervention of the state in the economy, by a free market economy. Therefore, the Spanish context constitutes a unique social laboratory (Lancaster, 1989) to study 
continuity and change in the structure of the professions (Martín-Moreno and De Miguel, 1982).

In our search for evidence for this investigation, we drew upon primary data on sex and date of admission of ICJCE's members from both its archives and yearbooks published for the period 1942 to 1988 . The yearbooks contained the following data about each ICJCE member: name, professional address, date of entry to the ICJCE and status of the auditor (e.g., active or auditor on leave), and were published in 1952, 1972, 1978, 1979, 1982, 1984 and 1988. The resulting database contains information on 5,946 individuals (that is, the entire membership of the ICJCE) as kept in the records of the institution. We have also drawn on secondary sources to outline the wider contexts of the audit profession during our period of study.

We encountered problems in gaining access to other sources of data (e.g., interviews with women who became members of the ICJCE in the 1960s) and, thus, we deem this study as preliminary and suggestive of the role of gender in the Spanish audit profession. We none the less think that this investigation may be of interest for several reasons. First, the institutional context of the audit profession exerts an enduring influence on its organization. By studying the Spanish audit profession, we expect to contribute to the sparse, though growing, number of studies addressing professionalization issues in contexts different from those characterizing a limited group of Anglo-Saxon countries: the UK and the US (e.g., Hantrais, 1995; Ballas, 1999; García Benau et al., 1999; Annisette, 2000) and, thus, contribute to the overall debate on the role of gender in the development of the audit profession. Second, in spite of the considerable efforts made by some researchers to embed gender studies into their wider societal context (e.g., Kirkham and Loft, 1993), we concur with Roberts and Coutts's (1992: 379) contention that there is still much to learn about the interface between gender and the context of the audit profession. Particularly, our investigation of the Spanish profession during the period 1942-88 may shed some light on the role of the state as an overriding factor in the organization of the profession.

The remaining parts of this paper are structured as follows. The paper starts with a description of the wider societal context of the Spanish audit profession during our observation period as well as the data gathered from the archives of the ICJCE. This is followed by a discussion of our results, an outline of the shortcomings of this investigation as well as some suggestions for future research in this area.

\section{THE SETTING}

There are traces of some early attempts to set up associations of professional accountants ${ }^{1}$ in Spain at the beginning of the twentieth century (see Ruíz Blanco, 1998). The Institute of Public Accountants of Spain (Instituto de Contadores Públicos de España) might be considered as the earliest initiative to establish a professional body aimed at organizing the accountancy profession. It was 
founded in 1913 but disappeared without undertaking operations. In 1927, the Bilbao Institute of Sworn-in Accountants (Instituto de Contadores Jurados de Bilbao) was founded and it became the exemplar to be imitated by those set up in Cataluña (1931), Madrid (1936) and Vigo (1936). As noted by Ruíz Blanco (1998: 96), the foundation of these professional institutions was seemingly a domestic response to the operations in Spain of some foreign firms of chartered accountants (e.g., Turquand Barton Mayhew, and Price Waterhouse).

While the institutes had slightly different entry requirements, the following were common to them all. The entrant had to: (i) be at least 25 years old, (ii) hold at least an undergraduate degree in commercial studies, (iii) have had four years of professional practice, (iv) not have a criminal record and (v) be certified as a good citizen. ${ }^{2}$ Interestingly, the entry requirements did not exclude women from entry into the profession, and this might be motivated by their increasing professional qualifications. As shown by the Spanish Institute of Statistics (Instituto Nacional de Estadôticas, INE), the percentage of women enrolled in commercial schools increased from $20.2 \%$ in 1930 to $31.1 \%$ in 1936 (see INE, 1944).

As a result of the Spanish Civil War (1936-9), the country was ruled during the period from 1939-75 by a far right-wing, military dictatorship, led by General Franco. The dictatorship suppressed civil, political and working rights (e.g., freedom of speech, unions, political parties) and deployed harsh repression over those with a different ideology. As far as the participation of women in the public spheres of life was concerned, the dictatorship instigated changes aimed at instilling in society the fundamentals of the traditional role of women as housewives. For example, the 1938 Working Rights Act (Fuero del Trabajo), drawing on the doctrine of the Catholic Church (Fagoaga, 1963: 23), enacted 'the liberation of married women from workshops and factories' as a fundamental principle of the regime. This resulted in women being forced to give up their jobs at the time of marriage. The principle was subsequently developed by a number of civil and commercial laws. Such legislative developments established the practice of demanding the written consent of husbands, for wives to have any public or working activity. In short, the gender ideology of the dictatorship was summarized in the Spanish Civil Code (Article 47): 'husbands must protect their wives and wives must obey their husbands'. Further, the state deployed different educational patterns for boys and girls (Alberdi, 1993). Accordingly, the law of 17 July 1945, which enforced the educational policy of the dictatorship, established that boys should be instructed for a professional life in 'industry, commerce or agriculture', whereas girls should receive education for their future work 'at home and handicrafts'.

The new environment affected the incipient projects of audit professionalization witnessed during the Second Republic. Whereas the institutes of Vigo and Cataluña ceased operations at the outset of the civil war (1936), those of Madrid and Bilbao slowed down their activities during the war and merged into the newly founded ICJCE (1942), which became the sole professional association of 
auditors. The by-laws of the ICJCE were approved in 1945 and introduced the following entry requirements (Article 46): (i) Spanish citizenship, male, of at least 25 years; (ii) membership of any of the existing CTMs; (iii) certification in mercantile studies (Intendente Mercantil) or actuarial sciences (Actuario de Seguros); (iv) not have a criminal record; and (v) not have a record of professional misbehaviour. In short, such entry requirements explicitly banned women from audit practice as membership to the ICJCE was compulsory to carry on such activity (see Table 1).

The ICJCE mimicked the gender beliefs and values that characterized its wider social and political environments. Accordingly, the by-laws of the ICJCE drew on extant definitions of gender inferiority and enacted the monopolization of audit opportunities by one group (men) at the expense of another group (women), which was regarded as an outsider. In other words, the audit profession was subject to a process of closure (Weber, 1978: 342), which implied that women were regarded as 'ineligible' for the audit practice on mere gender grounds (Parkin, 1979: 450). By doing this, the ICJCE followed the extant, wider legislation that restricted the access of women to the public spheres of life (see the Working Rights Act of 1938).

The ICJCE developed an active lobbying policy aimed at gaining state recognition for audit practice, as well as the legal enforcement of audits of limited liability companies. Nevertheless, such demands of the ICJCE were only partially enshrined in the influential Companies Law of 1951. Whereas the Companies Law endorsed the ICJCE as the sole professional body of Spanish auditors, audits only were made compulsory in the exceptional case in which they were demanded by a firm's shareholders. Even in such exceptional circumstances, the scope of audits did not embrace crucial issues such as the notes to financial statements and the distribution of earnings. Later, the Law of Listed Companies of 1964 represented a further failed attempt by the state at making audits

Table 1 New members of the ICJCE, 1942-88

\begin{tabular}{lcccc}
\hline Years & $\begin{array}{l}\text { All new } \\
\text { members }\end{array}$ & $\begin{array}{l}\text { Number } \\
\text { of men }\end{array}$ & $\begin{array}{l}\text { Number } \\
\text { of women }\end{array}$ & $\begin{array}{l}\text { Women as a percentage of } \\
\text { all new members }\end{array}$ \\
\hline $1942-45$ & 113 & 113 & 0 & 0.00 \\
$1946-55$ & 408 & 408 & 0 & 0.00 \\
$1956-65$ & 831 & 828 & $3^{\mathrm{a}}$ & 0.36 \\
$1966-75$ & 331 & 329 & 2 & 0.60 \\
$1976-80$ & 1,657 & 1,595 & 62 & 3.74 \\
$1981-84$ & 1,260 & 1,166 & 94 & 7.46 \\
$1984-88$ & 1,346 & 1,162 & 184 & 13.67 \\
$\mathbf{1 9 4 2 - 8 8}$ & $\mathbf{5 , 9 4 6}$ & $\mathbf{5 , 6 0 1}$ & $\mathbf{3 4 5}$ & $\mathbf{5 . 8 0}$ \\
\hline
\end{tabular}

Note:

aDate of admission: 1965 .

Source: Authors. 
compulsory. Although the 1964 law apparently made some progress in that direction, by establishing that: 'listed companies are obliged to report their notes, balance sheets, and profit and loss accounts to the supervisory authority [of the stock market] and should be certified by a graduated technician, member of the ICJCE...' (Article 21), the supervisory authority of the Madrid Stock Exchange (MSE) made a narrow interpretation of this clause. Instead of demanding the submission of audited financial statements from listed companies, the authority interpreted this legal statement as a requirement for certification by an ICJCE member that there was agreement between the financial statements forwarded to the stock exchange and those kept at the firm's headquarters.

During the 1960s, the ICJCE deployed an active policy of co-operation with some associations of civil servants (e.g., tax inspectors), which aimed at gaining support for the ICJCE and the practice of auditing from within the public sector. Interestingly, the agreements enacted a clause that granted access to the audit profession to any qualified civil servant upon application. Such agreements explain the entry of three women into the ICJCE in spite of the ban on female admission that was enacted in the by-laws of the association.

The economic and political environment of Spain during the dictatorship may help to explain both the limited scope of audits and the low-profile role of the ICJCE in galvanizing the audit profession. First, as was widely advertised by the propaganda of the regime, General Franco held himself accountable only 'before God and history'. Therefore, practices of accountability did not fit with the wider societal values enforced by the dictatorship but, conversely, were perceived as an attempt to erode one of its fundamental principles (e.g., Núñez et al., 1999). Second, as the MSE was not reliable enough to attract foreign investments (e.g., poor quality of firms' financial information to external parties, intervention of the Spanish central bank in support of some stocks) its volume was far below that of its European counterparts. The MSE, thus, had a domestic focus and had become a mere extension of the system of economic autarchy that governed Spain. In such a parochial context, stock market practices - such as audits - simply mimicked the wider societal values of non-accountability.

The twilight of the dictatorship witnessed some timid attempts to improve the regime's deficit in human rights. The reform of the Civil Code of May 1975 removed the clause requiring the written consent of husbands for wives to be involved in professional and business activities. In this context, the ICJCE reformed its by-laws in July 1977 to omit the requirement to be a male as a condition for membership.

The advent of democracy and the enactment of the Spanish Constitution of 1978 required the transformation of the institutions of the dictatorship to the standards of a full-fledged Western democracy. This implied a tight programme of legislative reforms that embraced every aspect of the Spanish social, economic and political life. The international community sanctioned that process by endorsing the entry of Spain into institutions such as the North Atlantic Treaty Organization (NATO) (1981) and the European Economic Community (EEC) 
(1986). The liberalization of the economy affected the audit practice through the removal of the legal status of the ICJCE as the sole professional body of auditors. Accordingly, membership to the ICJCE was no longer mentioned in the legal texts as a requirement to conduct audits (e.g., the 1981 reform of the by-laws of the stock market omitted any reference to the ICJCE) and, thus, the ICJCE lost its privilege of being the sole association of auditors which enjoyed legal endorsement. The end of the unique, legal status of the ICJCE brought about the foundation of other professional associations of auditors such as the Register of Economists-Auditors (Registro de Economistas Auditores, REA), in 1982.

\section{WOMEN IN THE PROFESSIONS}

In spite of the state's policy of instructing girls for their future work 'at home and handicrafts', women achieved considerable educational qualifications during the dictatorship period. As noted by Durán (1972: 49), however, increasing educational qualifications of women did not enhance their participation in top-tier professions during the 1960s. For example, after extensive searches in the archives of different professional associations, Gutiérrez (1968: 16) found no trace of female membership in professions like stock market brokerage and civil engineering. In other equally 'elite' professions (e.g., full professorships in Spanish universities), gender issues also played a significant role, as shown by the fact that just nine women became full professors by 1968 .

The advent of the Spanish democracy enhanced the profile of women in liberal professions. As expected, the gender restrictions to professional employment were removed from the law, and this permitted female access to professions such as the bench and auditing. Further, social barriers to 'elite' professions softened, as shown in the case of the medical profession, which increased the proportion of women from 2.09\% in 1964 (Anuario Estadếtico de 1964: Ch. VIII) to $17.46 \%$ in 1976 (Encuesta de Población Activa, EPA, 1976) and to 28.79\% in 1988 (EPA, 1988). Interestingly, the percentage of women who graduated in medicine was $8.05 \%$ in 1964, and this provides some support for Durán's (1972) contention about the gap between the educational qualifications of women and their problematic access to some liberal professions.

The audit profession also witnessed a gap between educational qualifications of women and their participation in the audit practice. Whereas the proportion of women enrolled in schools of commerce during our observation period remained around $24.6 \%$ (INE), their access to the audit practice was banned by law. This, we argue, might explain why qualified women were concentrated in second-tier jobs (e.g., bookkeepers). In 1976, the proportion of women who were hired as bookkeepers was $29.29 \%$ (EPA, 1976), and such participation significantly decreased to $9.69 \%$ in 1988 (EPA, 1988).

As noted above, the liberalization of the Spanish economy removed the privileged status of the ICJCE as the sole association of auditors. During the period 1976-80, that is, on the eve of the enforcement of the reforms, the ICJCE 
attempted to become the first entrant into the new, free market for professional services in Spain and, thus, deployed an active policy of recruitment. Accordingly, it increased its membership by $98.45 \%$ during the period 1976-80. Competition from other professional bodies (e.g., REA) slowed down the pace of membership increases during the periods 1981-84 and 1985-88 (see Table 1). However, the ICJCE still increased its membership by $78.02 \%$ during 1981-88, as an outcome of the expanding Spanish market for audit services. The proportion of women who became members of the ICJCE increased from $0.36 \%$ (3) to $5.80 \%$ (345) during the period 1965-88 (see Table 1).

\section{DISCUSSION}

Extant knowledge on gender and accountancy overwhelmingly relies on evidence gathered from a limited group of Anglo-Saxon countries such as the UK and the US (e.g., Lehman, 1992; Kirkham and Loft, 1993). Although this literature provides many perceptive insights into our understanding of the role of gender in the practice of audit, it is widely admitted that gender issues are significantly affected by the institutional settings of the investigation (e.g., Roberts and Coutts, 1992; Hammond, 1997b: 686). Our study addresses the role of women in the audit profession by drawing on a context characterized by the peaceful transition from a dictatorship to a full-fledged democracy as well as by the emergence of a free market economy from an economic system characterized by a stiff autarchy and an overriding state intervention in the economy.

Our research reveals that the Spanish professional bodies played a low-profile role in the organization of the audit profession. First, the ICJCE was founded in 1942, that is, several decades after its Anglo-Saxon counterparts were well under way (e.g., Lehman, 1992; Kirkham and Loft, 1993; Chua and Poullaos, 1993; Richardson, 1997). This late organization of the profession may be attributed to the low demand for audits in Spain, which in turn may be explained by (i) the overwhelming role of family business in the Spanish economy and its reservation to stock market listings (e.g., Gómez-Mejía et al., 2001), and (ii) the turbulent political environment that characterized the country since the beginning of the nineteenth century. The civil wars that devastated Spain and the loss of its transatlantic empire, we contend, exemplify the latter aspect. The interplay of family business and political turmoil, we argue, rendered the regulation of the audit market a low priority on the political agenda. This lack of legislative support acted as a considerable constraint on the development of the audit profession, especially in a setting where the state enjoyed a long tradition of interventionism in the economy (Carmona and Macías, 2001).

Second, the enactment of audit legislation during our observation period did not invest the audit practice with its regular scope. Instead of considering the practice of auditing as a professional service aimed at providing an independent judgement on the fairness and risk of financial statements, the Spanish legislation limited the concept of the audit to a mere certification of conformity between 
published and in-house financial statements (Bercovitz, 1985). Fernández Peña (1985: 366-7) argued that this limited scope of audit practice weakened the position of the ICJCE as a representative of the Spanish audit profession.

Third, in accordance with the prediction of Macdonald (1995: 96) for countries that underwent recent fascist regimes (e.g., Spain, Italy and Japan), the ICJCE was unable to develop an autonomous strategy for the Spanish audit profession. Instead, there existed a strong dependence of the ICJCE on the state, and this, we contend, may help explain the role of gender in the Spanish audit profession. As noted above, the ICJCE was founded as a result of the provisions enshrined in the decree of 15 December 1942, which authorized the Board of the High Associations of Commercial Graduates (Consejo Superior de Titulares Mercantiles) to set up an auditing professional body. In its origins, thus, the ICJCE did not emerge as a pure professional initiative. In the context of the outset of the dictatorship, it ultimately owed its existence to a state's decree.

Conformity of the ICJCE with the principles of the dictatorship was a requirement for the survival of the institution, and this affected its policy on the role of women in the audit profession. During the dictatorship, the status of women in the public spheres of life was the outcome of the intertwinement of the two institutions that formed the winning coalition of the Spanish Civil War, namely: the military forces and the Catholic Church. Interestingly, these institutions were entirely male and, thus, their male-based view of social life was deployed into Spanish society, as enshrined in the 1938 Working Rights and the Civil Code. By doing this, the dictatorship conformed with Connell's (1987) prediction that non-democratic states engage in considerable activity to regulate gender issues. In this context, the ICJCE did not implement a conscious strategy for the exclusion of women but just adopted the corresponding state's policies in that matter (Witz, 1992; Macdonald, 1995). In our view, the ICJCE by-laws of 1945 did not independently define women as an ineligible group to become its members (Parkin, 1979). Instead, they just mimicked the dominant gender values that were deployed by the armed forces and the Catholic Church and, thus, rendering the ICJCE an all-male institution.

In a similar vein, there was no resistance on the part of the ICJCE towards easing the access of women to the audit practice when their civil rights were restored at the outset of the democracy. The ICJCE's passive role contrasts with the resistance of the Institute of Chartered Accountants of England and Wales to the state's pressures to ease the access of women into the profession (e.g., Kirkham and Loft, 1993: 529-32).

There are no traces of women's resistance against the legal ban on their eligibility to membership of the ICJCE. This may be explained in the overall context of the dictatorship's prohibition of trade unions and harsh repression of civil rights (Durán, 1972: 32). Arguably, such passive attitudes followed from their low probability of success as well as the penal consequences that a civil unrest certainly would have had for those arguing for the restoration of women's rights. Accordingly, women's membership to the ICJCE was considerably delayed 
with respect to its Anglo-Saxon counterparts. Whereas it was only in 1965 that the first women became members of the ICJCE, in 1885 a woman was admitted as a Chartered Accountant in Ontario (e.g., McKeen and Richardson, 1998), and in 1909 the London Association of Accountants admitted its first female member (Lehman, 1992).

\section{CONCLUSIONS AND LIMITATIONS}

Our findings reveal that the ICJCE failed in both galvanizing the Spanish audit profession and investing it with autonomy and social status. This conclusion conforms with Macdonald's (1995) prediction on the lack of autonomous professional projects in countries ruled by Fascist regimes. In such a context, the ICJCE had a low-profile role with respect to the overriding state legislation, which in turn affected the ICJCE's policies towards the exclusion of women from the practice of auditing. Our research reveals that exclusionary practices in the Spanish audit profession merely conformed with the wider societal values of discrimination towards women with respect to access to the public spheres of life. Interestingly, however, our data partly depart from Parkin's (1979) and French and Meredith's (1994) finding that exclusionary practices from the profession are accompanied by concomitant strategies of preventing the access of women towards crucial resources such as skills and knowledge. As noted above, the state's policy of focusing girls' education on their future work 'at home and handicraft' did not properly succeed. Women steadily increased their educational qualifications during the late dictatorship and this background became instrumental for their participation in liberal professions since the outset of the Spanish democracy, in 1976.

We also found a passive role of the ICJCE towards gender issues when legislation restricting the access of women to public spheres of life was removed in the democratic period. Instead of deploying attitudes of resistance like the ICAEW (see Kirkham and Loft, 1993), the ICJCE conformed with extant legislation and omitted in its by-laws the ban towards female membership. This episode, we contend, depicts conformity of the ICJCE with the state's policy on gender issues and suggests its dependence on the state and lack of an autonomous professional project. ${ }^{3}$

As noted at the outset of the paper, this is a preliminary study on the role of the state in gender issues. This investigation, thus, contains some limitations that may encourage future work. First, we have collected extensive, archival data on membership of the ICJCE since its inception to 1988 in an attempt to study the deployment of gender notions in the Spanish audit profession. Such data, however, may be well complemented by the undertaking of qualitative research focusing on those women who did become members of the ICJCE at a time during which they were legally excluded from the audit practice, in line with the work done by Hammond (1997a) on Afro-American women accountants. Second, the development of comparative studies on gender practices in accountancy has 
been widely neglected (see Hantrais, 1995, for a significant exception). We believe that cross-national studies of settings that did not experience adequate conditions for fairly autonomous organization of audit practice (e.g., nondemocratic regimes), namely: Germany and Italy (e.g., Macdonald, 1995) may shed some light on the role of gender in the audit profession. Such studies may be crucial to ascertain the generalizability of our conclusions, that is, to what extent countries ruled by dictatorships witnessed a weak organization of the audit profession and a passive attitude of professional associations towards the exclusion of women from the audit practice. Lastly, our investigation is restricted to the audit profession without providing comparative analysis with subordinate occupations such as accounts clerk/bookkeeper (e.g., Kirkham and Loft, 1993; Cooper and Taylor, 2000), which may illuminate strategies of differentiation of the auditing profession towards such jobs.

\section{ACKNOWLEDGEMENTS}

Research has been partly funded by the CICYT's (Spain) projects SEC 98-0282 and SEC 2000-0395. We would like to thank the Instituto de Censores Jurados de Cuentas de España for providing us with free access to its archives as well as the Alberta School of Business for its research support during summer 2000. The authors have benefited from the many constructive comments made by Marcia Annisette, the participants at the EAA Annual Congress, Munich, 2000, as well as from the suggestions provided by the two anonymous EAR referees. The encouragement and support of Peter Walton is especially appreciated.

\section{NOTES}

1 The boundaries between the accountancy profession (contadores, contables) and the audit profession (auditores, contadores jurados, censores jurados) were blurred until the inception of the ICJCE. Since the beginning of the twentieth century, the audit profession constituted a segment of the wider accountancy profession, which was organized around the Associations of Graduates in Commerce (Colegios de Titulares Mercantiles, CTMs), whose entry requirement mainly consisted of academic qualifications. As shown below, the CTMs played an instrumental role in setting up the ICJCE, which in the 1970s became independent from the CTMs.

2 This document was issued by a local judge and reported on an individual's (lack) of criminal records in the development of civil and business activities.

3 Some professions defied the new state's regulation on gender issues. For example, the Spanish notarios (certified lawyers), which are instrumental in providing legal endorsement to most civil and mercantile transactions, still required during the second half of the 1970 s the legal consent of husbands for wives to carry on business activities.

\section{REFERENCES}

Alberdi, I. (1993) 'Actividad laboral de las mujeres', in Del Campo, S. (ed.) Tendencias Sociales en España (1960-1990), Vol. 1. Bilbao: Ed. Fundación BBV. 
Anderson, J. C., Johnson, E. N. and Reckers, P. M. J. (1994) 'Perceived effects of gender, family, and physical appearance on career progression in public accounting', Accounting, Organizations and Society, 19(6): 483-91.

Annisette, M. (2000) 'Imperialism and the professions: the case of Trinidad and Tobago', Accounting, Organizations and Society, 25(7): 631-59.

Ballas, A. (1999) 'Privatizing the statutory auditing services in Greece', Accounting, Business and Financial History, 9(3): 349-74.

Bercovitz, A. (1985) 'Situación actual y perspectivas de la regulación legal de la auditoría', in Registro de Economistas Auditores (eds) La Regulación de la Auditoría en España. Madrid: Registro de Economistas Auditores, pp. 57-65.

Bougen, P. D. (1997) 'Spain, July 1988: some observations on becoming professional', Accounting, Organizations and Society, 22(8): 757-77.

Bougen, P. D. and Vázquez, D. (1997) 'Debating Spanish audit legislation: the audit law of 1988', European Accounting Review, 6(1): 1-17.

Carmona, S. and Macías, M. (2001) 'Institutional pressures, monopolistic conditions, and the implementation of early cost systems', Abacus, 37(2): 139-65.

Chua, W.-F. and Poullaos, C. (1993) 'Rethinking the profession-state dynamic: the case of the Victorian charter attempt, 1885-1906', Accounting, Organizations and Society, 18(7/8): 691-728.

Chua, W.-F. and Poullaos, C. (1998) 'The dynamics of "closure" amidst the construction of market, profession, empire and nationhood: an historical analysis of an Australian accounting association', Accounting, Organizations and Society, 23(2): 155-87.

Connell, R. W. (1987) Gender and Power: Society, the Person and Sexual Politics. Cambridge: Polity Press.

Cooper, C. and Taylor, P. (2000) 'From Taylorism to Ms Taylor: the transformation of the accounting craft', Accounting, Organizations and Society, 25(6): 555-78.

Crompton, R. and Sanderson, K. (1990) Gendered Jobs and Social Change. London: Unwin Hyman.

Durán, M. A. (1972) El Trabajo de la Mujer en España. Un Estudio Sociológico. Madrid: Editorial Tecnos.

Fagoaga, M. (1963) 'El fuero del trabajo y la doctrina social de la iglesia', Revista de Política Social, 58 (April-June): 23-45.

Fernández Peña, E. (1985) 'XX años de censura de cuentas en la legislación y en la práctica bursátil española', in Registro de Economistas Auditores (eds) La Regulación de la Auditoría en España. Madrid: Registro de Economistas Auditores, pp. 364-83.

French, S. and Meredith, V. (1994) 'Women in public accounting: growth and advancement', Critical Perspectives on Accounting, 5: 227-41.

García Benau, M. A. and Humphrey, C. (1992) 'Beyond the audit expectations gap: learning from the experiences of Britain and Spain', European Accounting Review, 1: 303-31.

García Benau, M. A., Ruíz Barbadillo, E., Humphrey, C. and Al Husaini, W. (1999) 'Success in failure? Reflections on the changing audit environment', European Accounting Review, 8(4): 701-30.

Gómez-Mejía, L., Núñez, M. and Gutiérrez, I. (2001) 'The role of family ties in agency contracts', Academy of Management Journal, 44(1): 81-95.

Gutiérrez, I. (1968) La Mujer Dirigente en las Profesiones Liberales. Barcelona: Eidos.

Hammond, T. (1997a) 'From complete exclusion to minimal inclusion: African Americans and the public accounting industry, 1965-1988', Accounting, Organizations and Society, 22(1): 29-54.

Hammond, T. (1997b) 'Culture and gender in accounting research', Critical Perspectives in Accounting, 8(6): 685-92.

Hantrais, L. (1995) 'A comparative perspective on gender and accountancy', European Accounting Review, 4(2): 197-215. 
Hopwood, A. G. (1987) 'Accounting and gender: an introduction', Accounting, Organizations and Society, 12(1): 65-9.

INE. Anuario Estadístico (1944). Madrid: Instituto Nacional de Estadística.

Jarausch, K. H. (1990) The Unfree Professions. German Lawyers, Teachers, and Engineers, 1900-1950. Oxford: Oxford University Press.

Kirkham, L. (1992) 'Integrating herstory and history in accountancy', Accounting, Organizations and Society, 17(3/4): 287-97.

Kirkham, L. M. and Loft, A. (1993) 'Gender and the construction of the professional accountant', Accounting, Organizations and Society, 18(6): 507-58.

Lancaster, T. D. (1989) Policy Stability and Democratic Change. University Park, PA: Pennsylvania University Press.

Lehman, C. R. (1992) "'Herstory" in accounting: the first eighty years', Accounting, Organizations and Society, 17(3/4): 261-85.

Macdonald, K. (1995) The Sociology of the Professions. London: Sage Publications.

Martín-Moreno, J. and De Miguel, A. (1982) Sociología de las Profesiones. Madrid: Centro de Investigaciones Sociológicas.

McKeen, C. A. and Richardson, A. (1998) 'Education, employment and certification: an oral history of the entry of women into the Canadian accounting profession', Business and Economics History: 500-21.

Mynatt, P. G., Omundson, J. S., Schroeder, R. G. and Stevens, M. B. (1997) 'The impact of Anglo and Hispanic ethnicity, gender, position, personality and job satisfaction on turnover intentions: a path analytic investigation', Critical Perspectives on Accounting, 8(6): 657-84.

Núñez, M., Gutiérrez, I. and Carmona, S. (1999) 'Organizational accountability and firms' chances of survival: an empirical investigation of the Spanish newspaper industry (1966-1993)', Carlos III University Working Paper Series (Business Economics).

Oakes, L. and Hammond, T. (1995) 'Biting the epistemologicalhand: feminist perspectives on science and their implications for accounting research', Critical Perspectives on Accounting, 6(1): 49-75.

Parkin, F. (1979) Marxism and Class Theory: A Bourgeois Critique. New York: Columbia University Press.

Richardson, A. (1997) 'Social closure in dynamic markets: the incomplete professional project in accountancy', Critical Perspectives on Accounting, 8(6): 635-53.

Roberts, J. and Coutts, J. A. (1992) 'Feminization and professionalization: a review of an emerging literature on the development of accounting in the United Kingdom', Accounting, Organizations and Society, 17(3/4): 379-95.

Ruíz Blanco, S. (1998) 'El colegio de contadores de Cataluña', Revista Técnica, 12: 94-105.

Tinker, T. and Neimark, M. (1987) 'The role of annual reports in gender and class contradictions at General Motors: 1917-1976', Accounting, Organizations and Society, 12(1): 71-88.

Torstendahl, R. and Burrage, M. (1990) The Formation of Professions. Knowledge, State and Strategy. London: Sage Publications.

Tyson, T. (1988) 'Grade performance in introductory accounting courses: why female students outperform males', Issues in Accounting Education, 4: 153-60.

Weber, M. (1978) Economy and Society. Berkeley, CA: University of California Press.

Witz, A. (1992) Professions and Patriarchy. London: Routledge.

Witz, A. (1997) 'Women and work', in Robinson, V. and Richardson, D. (eds) Women's Studies. New York: New York University Press. 